\title{
RANCANG BANGUN NERACA ASET FISIK DAN MONETER SUMBER DAYA PERIKANAN TANGKAP LAUT INDONESIA 2002-2011
}

\author{
(Design of Physical and Monetary Asset Balance Sheet for Indonesian Marine Capture \\ Fisheries Resources 2002-2012)
}

\author{
Fikri Nata Prasetiawan', Abdul Rachman² \\ Politeknik Statistika STIS ${ }^{1}$ \\ Politeknik Statistika STIS ${ }^{2}$ \\ Jl. Otto Iskandardinata No. 64 C Jakarta 13330 \\ E-mail: fikrinata.prasetiawan@gmail.com
}

\begin{abstract}
ABSTRAK
Permasalahan overfishing Indonesia erat kaitannya dengan lemahnya pengelolaan perikanan tangkap laut karena tidak tersedianya kerangka statistik sebagai dasar kebijakan. Oleh karena itu, penyediaan kerangka statistik sebagai dasar pertimbangan perumusan kebijakan pengelolaan perikanan tangkap laut Indonesia penting dilakukan. Penelitian ini bertujuan untuk melakukan perancangan dan pembangunan neraca aset fisik dan moneter sumber daya perikanan tangkap laut Indonesia secara agregatif dari 11 wilayah perairan pantai tahun 2002-2011. Kerangka penyusunan neraca didasarkan kepada kerangka System of EnvironmentalEconomic Accounting Agriculture, Forestry and Fishery (SEEA-AFF). Penyusunan neraca aset fisik menggunakan pemodelan bioekonomi Gordon-Schaefer dengan variasi model Schnute dan Clark Yoshimoto Pooley (CYP) untuk menghitung stok dan dinamika biomassa sumber daya perikanan tangkap laut. Teknik estimasi parameter regresi yang digunakan adalah model regresi data panel. Sedangkan, valuasi resource rent digunakan dalam penyusunan neraca aset moneter. Hasil neraca tersusun menunjukkan bahwa terdapat kondisi economic overfishing di sejumlah wilayah perairan pantai. Kondisi tersebut merupakan keadaan yang merugikan baik bagi ekonomi penangkapan maupun biomassa sumber daya perikanan tangkap laut Indonesia. Hasil penyusunan neraca aset sumber daya perikanan tangkap laut dalam penelitian ini diharapkan dapat digunakan sebagai dasar perumusan kebijakan dan rujukan pengembangan penyediaan kerangka statistik resmi dalam pengelolaan sumber daya perikanan tangkap laut Indonesia.
\end{abstract}

Kata kunci: perikanan tangkap laut, pemodelan bioekonomi, overfishing

\section{ABSTRACT}

Indonesian overfishing problems are closely related with the weakness of marine fisheries management caused by unavailability of statistical framework as policy's base. Based on that, statistical framework establishment as policy's base is important to do. This research aims to establish aggregative physical and monetary asset accounts of Indonesian marine fisheries resources as aggregative accounts from 11 coastal areas for period 2002-2011. System of Environmental-Economic Accounting Agriculture, Forestry and Fishery (SEEA-AFF) framework used in the making of Indonesian marine fisheries resources accounts. Physical asset account use Gordon-Schaefer bioeconomic modelling with Schnute and Clark, Yoshimoto, Pooley (CYP) variations to estimate stock and dynamics of marine capture fisheries resources. Parameter estimation technique used in this research is panel data regression model. Whereas, resource rent valuation used in the making of monetary asset account. Composed accounts show that there is economic overfishing in some Indonesian coastal areas. This condition indicates a loss, both of fisheries business economy and fisheries resources biomass. Indonesian marine fisheries resources accounts in this research are expected to be policy's base and be reference of official statistical framework development of Indonesian marine capture fisheries.

Keywords:_marine capture fisheries, bioeconomic modelling, overfishing

\section{PENDAHULUAN}

Subsektor perikanan merupakan subsektor yang prospektif dan penting bagi perekonomian Indonesia. Data Kementerian Kelautan dan Perikanan (KKP) menunjukkan bahwa produksi perikanan Indonesia dalam kurun waktu 2002-2012 selalu mengalami kenaikan dengan rata-rata 
laju pertumbuhan sebesar 10,25\% per tahun. Selain itu, pada tahun 2005-2012 nilai produksi perikanan tangkap Indonesia didominasi oleh perikanan tangkap laut dengan sumbangan $91,78 \%$ dari total nilai produksi perikanan tangkap, sedangkan perikanan tangkap perairan umum menyumbang $8,22 \%$. Hal ini menunjukkan, bahwa apabila dipandang secara ekonomi perikanan tangkap laut merupakan bagian subsektor perikanan yang memberikan kontribusi terbesar dibandingkan bagian subsektor perikanan lain.

Tingginya usaha penangkapan perikanan laut berpotensi memberikan dampak negatif terhadap kelestarian sumber daya perikanan. Hasil kajian Pusat Riset Perikanan Tangkap (2002) menunjukkan bahwa terhadap perairan laut Indonesia, pemanfaatan sumber daya perikanan pada tahun 2002 sebesar $63,49 \%$ dari potensi biologis yang tersedia (80\% Maximum Sustainability Yield). Namun, apabila diteliti lebih jauh terdapat beberapa jenis sumber daya perikanan laut yang telah mengalami overfishing di beberapa Wilayah Pengelolaan Perikanan (WPP). Udang hampir mengalami overfishing diseluruh perairan Indonesia, kecuali Laut Sulawesi, Laut Arafura dan Samudera Pasifik, serta Samudera Hindia. Ikan karang konsumsi mengalami overfishing di perairan Selat Malaka, Laut Jawa, Laut Arafura, dan Samudera Hindia. Ikan demersal mengalami overfishing di perairan Selat Malaka, Selat Makasar, dan Laut Banda. Ikan pelagis kecil mengalami overfishing di perairan Laut Jawa dan Laut Banda. Ikan pelagis besar mengalami overfishing di perairan Selat Malaka dan Laut Jawa.

Overfishing dipandang sebagai krisis perikanan yang disebabkan oleh ketidakmampuan instrumen pengontrol penangkapan perikanan untuk bisa mengimbangi laju modernisasi teknologi penangkapan perikanan (Fujita, 2008). Hal ini mengakibatkan intervensi manusia, baik sebagai nelayan maupun pengelola, dalam penangkapan sumber daya perikanan menjadi tidak terkendali (Hilborn \& Walters, 1992). Permasalahan tersebut mendorong terjadinya kondisi mismanagement yang menjalar kepada kerugian sosial dan ekonomi (Atmaja S. B., 2011).

Berkenaan dengan penyediaan instrumen pengelolaan perikanan, pada tahun 2012, United Nations Statistics Division (UNSD) menerbitkan kerangka System of Environmental-Economic Accounting Agriculture, Forestry and Fishery (SEEA-AFF) sebagai kerangka terintegrasi antara ekonomi dan lingkungan yang terkait pertanian, kehutanan, dan perikanan. Badan Pusat Statistik (BPS) melalui Sistem Terintegrasi Neraca Lingkungan dan Ekonomi Indonesia sampai sekarang belum menerbitkan kerangka System of Environmetal-Economic Accounting for Fisheries (SEEAF) sebagai kerangka yang tidak terpisahkan dalam kerangka SEEA-AFF. Hal tersebut menjadikan SEEAF belum digunakan Kementerian Kelautan dan Perikanan (KKP) sebagai administrator perikanan Indonesia menjadi instrumen pengelolaan perikanan di Indonesia.

Pentingnya penyediaan kerangka SEEAF sebagai instrumen pengelolaan perikanan Indonesia untuk mencapai tujuan Sustainable Development Goals (SDGs) ke-14 yakni mengkonservasi dan memanfaatkan secara berkelanjutan sumber daya laut, samudera dan maritim untuk pembangunan yang berkelanjutan mendorong peneliti melakukan penelitian ini. Penelitian ini bertujuan untuk menyediakan kerangka neraca aset fisik dan moneter sumber daya perikanan tangkap laut Indonesia dengan mengambil periode percobaan tahun 2002-2011. Penyediaan kerangka neraca aset sumber daya perikanan tangkap laut ini terbagi dalam neraca nasional dan 11 neraca wilayah perairan pantai. Selain itu, sebagai tindak lanjut dari penyediaan neraca lingkungan perikanan laut, penelitian ini memberikan gambaran kondisi sumber daya perikanan laut dan opsi pengelolaannya.

\section{METODE}

\section{Landasan Teori}

Kerangka Neraca Aset Sumber Daya Perikanan (NSDP) tersusun atas dua kerangka neraca penyusun, yakni neraca aset fisik (physical asset account) dan neraca aset moneter (monetary asset account). Neraca aset fisik merupakan neraca yang mencatat volume stok dan dinamika perubahan stok sumber daya perikanan. Neraca aset fisik yang dibentuk umumnya memiliki periode satu tahun. Sedangkan neraca aset moneter sumber daya perikanan mencatat nilai stok dan dinamika perubahan stok sumber daya perikanan dalam satuan moneter. Penyusunan neraca aset moneter sumber daya perikanan terdiri dari dua tahap yakni pertama menentukan resource rent yakni nilai manfaat yang diperoleh atas sebab kepemilikan aset sumber daya, dan kedua menentukan proyeksi penilaian sumber daya perikanan. 
Dalam Neraca Aset Sumber Daya Perikanan (NSDP), perubahan yang dicatat adalah:

1. Stok sumber daya perikanan. Stok awal tahun ke- $t$ merupakan stok akhir setahun sebelum $t$ ditambah dengan dinamika perubahan stok perikanan yang terjadi;

2. Perubahan karena aktivitas penangkapan. Merupakan volume sumber daya perikanan yang ditangkap dari habitat melalui usaha-usaha penangkapan perikanan. Nilai perubahan stok yang terjadi adalah negatif;

3. Pertumbuhan alami sumber daya perikanan. Merupakan perubahan volume sumber daya perikanan yang dikarenakan proses kelahiran dan kematian alami yang secara biologis terjadi pada sumber daya perikanan non budidaya. Pertumbuhan ini menggunakan konsep Maximum Economic Yield (MEY);

4. Deplesi sumber daya perikanan. Merupakan perubahan stok biomassa perikanan yang sebagai akibat aktivitas penangkapan dan pertumbuhan stok biomassa sumber daya perikanan. Deplesi didefinisikan sebagai selisih antara pertumbuhan alami yang terjadi dengan volume penangkapan yang dilakukan;

5. Perubahan lain sumber daya perikanan. Merupakan perubahan lain yang tidak tercatat dalam aktivitas penangkapan maupun pertumbuhan alami sumber daya perikanan. Perubahan ini dapat berupa perubahan karena aktivitas seperti Illegal Unreported Unregulated Fishing (IUUF) dan perubahan katastropik lain.

Sumber daya perikanan laut merupakan sumber daya yang terhabiskan (exhaustible) dan yang dapat diperbaharui (renewable). Selain sebagai sumber daya yang terhabiskan (exhaustible) dan yang dapat diperbaharui (renewable), sumber daya perikanan laut merupakan sumber daya yang tidak dapat dicacah secara langsung stok dan dinamika perubahan biomassanya. Untuk mengkaji stok dan dinamika perubahan biomassanya diperlukan pemodelan untuk menduganya.

Pengkajian stok dan dinamika perubahan biomassa sumber daya perikanan tangkap dapat dilakukan dengan menggunakan model surplus produksi Schaefer. Secara umum, Schaefer menyatakan bahwa pertumbuhan (dalam berat biomassa) dari suatu populasi $(x)$ dari waktu ke waktu merupakan fungsi dari populasi awal. Selain itu, Schaefer mengemukakan bahwa tangkapan (yield) pada setiap waktu bergantung pada dua faktor, yaitu jumlah populasi ikan pada awal periode dan jumlah upaya penangkapan (effort) yang dilakukan. Schaefer mengembangkan fungsi produksi yang berdasarkan pada asumsi bahawa stok sumber daya bersifat homogen, fungsi pertumbuhan logistik, dan area terbatas. Sedangkan, dalam penangkapan yang mengoperasikan berbagai jenis alat tangkap maka diperlukan standardisasi alat tangkap, karena setiap jenis alat tangkap memiliki kemampuan tangkap yang berbeda-beda. Secara matematis, model Schaefer dengan standardisasi alat dapat dinyatakan sebagai berikut:

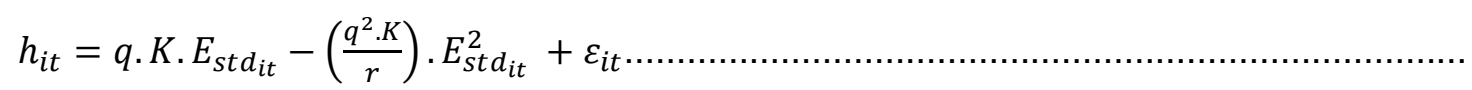

Berdasarkan Persamaan (1), apabila tidak ada aktivitas penangkapan $(E=0)$, maka hasil tangkapan juga nol. Apabila upaya terus dinaikkan sampai ke titik maksimum, pada titik $E_{M S Y}$ akan diperoleh produksi yang maksimum. Produksi pada titik ini disebut sebagai titik Maximum Sustainable Yield (MSY). Pada kurva yang bersifat kuadratik, maka peningkatan upaya yang terus menerus setelah melewati titik MSY tidak akan dibarengi dengan peningkatan produksi. Produksi akan turun, bahkan mencapai nol pada titik upaya maksimum (Emax) (Fauzi, 2005).

Menurut Fauzi (2005), model fungsi produksi Schaefer memiliki kelemahan secara metodologi dan analisis, karena parameter biologis $(r, q$ dan $K)$ tersembunyi dalam nilai $a$ dan $\beta$. Selain itu, model produksi hanya dapat mengetahui potensi produksi sumber daya perikanan dan tingkat produksi maksimum. Model belum mampu menunjukkan potensi industri penangkapan ikan dan belum dapat menentukan tingkat pengusahaan yang maksimum bagi nelayan. Teori ekonomi perikanan yang didasarkan atas sifat dasar biologis populasi ikan ditunjukkan untuk memahami perilaku ekonomi dari industri penangkapan ikan (Anderson, 1986). Pendekatan yang memadukan kekuatan ekonomi yang memengaruhi industri penangkapan dan faktor biologi yang menentukan produksi dan pasokan ikan disebut sebagai pendekatan bioekonomi (Clark, 1985).

Model statik dikembangkan pertama kali oleh Gordon dengan dasar fungsi produksi Schaefer (1954), sehingga disebut model Gordon-Schaefer. Pengembangan model Gordon-Schaefer dilakukan 
antara lain oleh Schnute (1987), dan Clark, Yoshimoto dan Pooley (1992). Oleh karena itu, terhadap model Schaefer perlu dilakukan modifikasi dengan menggunakan model bioekonomi berikut:

1. Model Schnute (1987)

$$
\begin{aligned}
& \ln \left(\frac{U_{i t+1}}{U_{i t}}\right)=r-\frac{r}{K q}\left(\frac{U_{i t}+U_{i t+1}}{2}\right)-q\left(\frac{E_{s t d_{i t}}+E_{s t d_{i t+1}}}{2}\right)+\varepsilon_{i t} \\
& \text { maka } \\
& \alpha=r, \beta=\frac{r}{K q}, \delta=q, K=\frac{\alpha}{\beta \delta}
\end{aligned}
$$

2. Model Clark, Yoshimoto, Pooley (CYP) (1992)

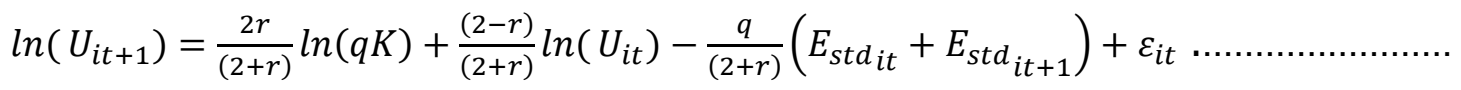

maka

$$
r=\frac{2(1-\beta)}{(1+\beta)} ; q=-\delta(2+r) ; \quad K=\frac{\exp \left(\frac{\alpha(2+r)}{2 r}\right)}{q}
$$

Keuntungan lestari (sustainable profit) dalam model bioekonomi akan diperoleh secara maksimum pada tingkat effort $E_{M E Y}$ di mana pada kondisi ini akan diperoleh rente ekonomi (economic rent) terbesar. Dalam literatur perikanan, tingkat effort $E_{M E Y}$ sering disebut sebagai Maximum Economic Yield (MEY), dan merupakan tingkat upaya yang optimal secara sosial (socially optimum). Tingkat effort yang dibutuhkan untuk mencapai titik optimal secara sosial $\left(E_{M E Y}\right)$ lebih kecil dibandingkan effortyang dibutuhkan untuk mencapai titik MSY $\left(E_{M S Y}\right)$. Hanneson, 1993 menjelaskan bahwa tingkat effort $E_{M E Y}$ terlihat lebih "conservative minded" atau lebih bersahabat dengan lingkungan dibandingkan dengan tingkat effort $E_{M S Y}$.

Nimmi (2012) dan Zuzy (2017) menurunkan persamaan bioekonomi sehingga didapatlah fungsi nilai biomassa optimal sebagai berikut:

$$
x_{i t}^{*}=\frac{K_{i}}{2}\left(1+\frac{c_{i t}}{q_{i} p_{i t} K_{i}}\right) \text {. }
$$

Selain itu, hasil tangkapan optimal MEY dapat ditulis sebagai berikut:

$$
h_{i t}^{*}=r_{i} x_{i t}^{*}\left(1-\frac{x_{i t}^{*}}{K_{i}}\right) \text {. }
$$

\section{Data dan Sumber Data}

Data yang digunakan dalam penelitian ini adalah data sekunder yang bersumber dari hasil Survei Rumah Tangga Usaha Penangkapan Ikan di Laut (SPI05) yang dilakukan Badan Pusat Statisitik (BPS), publikasi Badan Pusat Statisitik (BPS), serta publikasi Kementerian Kelautan dan Perikanan (KKP). Jenis data yang digunakan dalam penelitian ini adalah data panel 11 wilayah perairan pantai yang terdiri dari perairan pantai provinsi-provinsi pada periode 2002-2012.

Data yang digunakan dalam penelitian ini mencakup (1) Volume produksi sumber daya perikanan menurut jenis alat penangkapan ikan, wilayah perairan pantai, dan provinsi tahun 20022012; (2) Volume produksi sumber daya perikanan menurut kelompok sumber daya perikanan, wilayah perairan pantai, dan provinsi tahun 2002-2012; (3) Jumlah trip penangkapan ikan menurut jenis alat penangkapan ikan, wilayah perairan pantai, dan provinsi tahun 2002-2012; (4) Jumlah unit penangkapan ikan menurut jenis alat penangkapan ikan, wilayah perairan pantai, dan provinsi tahun 2002-2012; (5) Nilai produksi sumber daya perikanan menurut jenis kelompok sumber daya perikanan, wilayah perairan pantai, dan provinsi tahun 2002-2012; (6) Biaya penangkapan sumber daya perikanan menurut jenis biaya dan kelompok sumber daya perikanan 2002-2012; (7) Harga per unit sumber daya perikanan menurut jenis kelompok sumber daya perikanan dan wilayah perairan pantai tahun 2002-2012; (8) Resource rent per unit sumber daya perikanan menurut jenis kelompok sumber daya perikanan dan wilayah perairan pantai tahun 2002-2012; (9) Indeks Harga Perdagangan Besar (IHPB) subsektor perikanan tahun 2002-2012 (2005=100); (10) Catch per Unit Effort (CPUE) penangkapan sumber daya perikanan menurut wilayah perairan pantai dan provinsi tahun 2002-2012; dan (11) Effort standar penangkapan sumber daya perikanan menurut wilayah perairan pantai dan provinsi tahun 2002-2012. 


\section{Metode Analisis}

Penyusunan neraca aset fisik sumber daya perikanan tangkap laut dalam penelitian ini dihitung melalui pemodelan stok dan pertumbuhan sumber daya perikanan. Dalam penelitian ini terdapat dua opsi pemodelan bioekonomi yang digunakan yakni model bioekonomi Schnute dan Clark Yoshimoto Pooley (CYP). Persamaan dasar pemodelan yang digunakan dalam penelitian ini adalah Persamaan (2) untuk model bioekonomi Schnute, serta Persamaan (3) untuk model bioekonomi Clark Yoshimoto Pooley (CYP). Pemodelan pada masing-masing perairan pantai diestimasi menggunakan metode regresi data panel sebagai metode estimasi parameternya.

Salah satu dari kedua opsi pemodelan bioekonomi dipilih untuk masing-masing wilayah perairan pantai dengan menggunakan pertimbangan ekonometrik dan representasi hasil penghitungan parameter biologisnya. Kriteria ekonometrik dalam pemilihan model bioekonomi terdiri dari pengujian asumsi-asumsi regresi data panel terpilih yang meliputi pengujian asumsi normalitas, autokorelasi, multikolinieritas, dan pengujian struktur varians-kovarians homoskedastik.

Pemodelan dilakukan untuk mendapatkan parameter biologis yang mencakup intrinsic growth rate $(r)$, koefisien kemampuan tangkap $(q)$, dan daya dukung lingkungan $(K)$ yang digunakan untuk menghitung stok biomassa dan dinamika perubahan sumber daya perikanan tangkap. Stok biomassa sumber daya perikanan dihitung dengan Persamaan (4). Dinamika perubahan terdiri atas pertumbuhan stok biomassa, penangkapan, dan perubahan lain sumber daya perikanan tangkap. Pertumbuhan stok biomassa diukur atas kondisi Maximum Economic Yield (MEY) menggunakan Persamaan (5). Volume penangkapan merupakan volume penangkapan aktual yang dilakukan oleh nelayan berdasarkan data statistik perikanan tangkap Indonesia yang diterbitkan oleh Kementerian Kelautan dan Perikanan (KKP). Deplesi merupakan selisih antara pertumbuhan stok biomassa dengan volume tangkapan aktual. Sedangkan, volume perubahan lainnya adalah stok biomassa pada akhir tahun dikurangi stok awal dan deplesi sumber daya perikanan tangkap.

Neraca aset moneter disusun berdasarkan kerangka System of Environmental-Economic Accounting Fishery (SEEAF). Resource rent per unit sumber daya perikanan digunakan sebagai unit valuasi neraca aset fisik. Neraca aset moneter disusun berdasarkan 11 wilayah perairan pantai dengan periode tahun 2002-2011 yang menyusun satu neraca agregatif Indonesia. Neraca aset moneter disusun dengan aturan penyusunan berikut: (1) Nilai stok awal, pertumbuhan stok, penangkapan, deplesi, perubahan volume lainnya, dan stok akhir pada harga tahun berjalan pada tahun ke- $t$ dan wilayah perairan pantai ke- $i$ divaluasikan dengan resource rent tahun ke- $t$ dan wilayah perairan pantai ke-i, (2) Nilai stok akhir tahun ke- $t$ dan wilayah perairan pantai ke- $i$ divaluasikan dengan resource rent tahun ke- $t+1$ dan wilayah perairan pantai ke-i; (3) Nilai revaluasi tahun ke- $t$ dan wilayah perairan pantai ke- $i$ merupakan selisih antara nilai stok akhir pada harga tahun berjalan dengan nilai stok akhir tahun ke- $t$ dan wilayah perairan pantai ke-i.

\section{HASIL DAN PEMBAHASAN}

\section{Gambaran Produksi Sumber Daya Perikanan Tangkap Laut Indonesia}

Produksi perikanan tangkap yang berhasil didaratkan di wilayah perairan laut Indonesia periode 2002-2012 berkisar 4.073,51-5.435,81 ribu ton per tahun. Volume produksi perikanan tangkap pada periode tersebut mengalami pertumbuhan rata-rata sebesar 2,97\% per tahun. Produksi didominasi oleh sumber daya ikan pelagis kecil dengan volume produksi rata-rata sebesar $1.752,95$ ribu ton per tahun. Diikuti dengan sumber daya ikan demersal dengan volume produksi rata-rata sebesar $1.246,14$ ribu ton per tahun, dan sumber daya ikan pelagis besar dengan volume produksi rata-rata sebesar 1.052,92 ribu ton per tahun (Lihat Gambar 1.). 


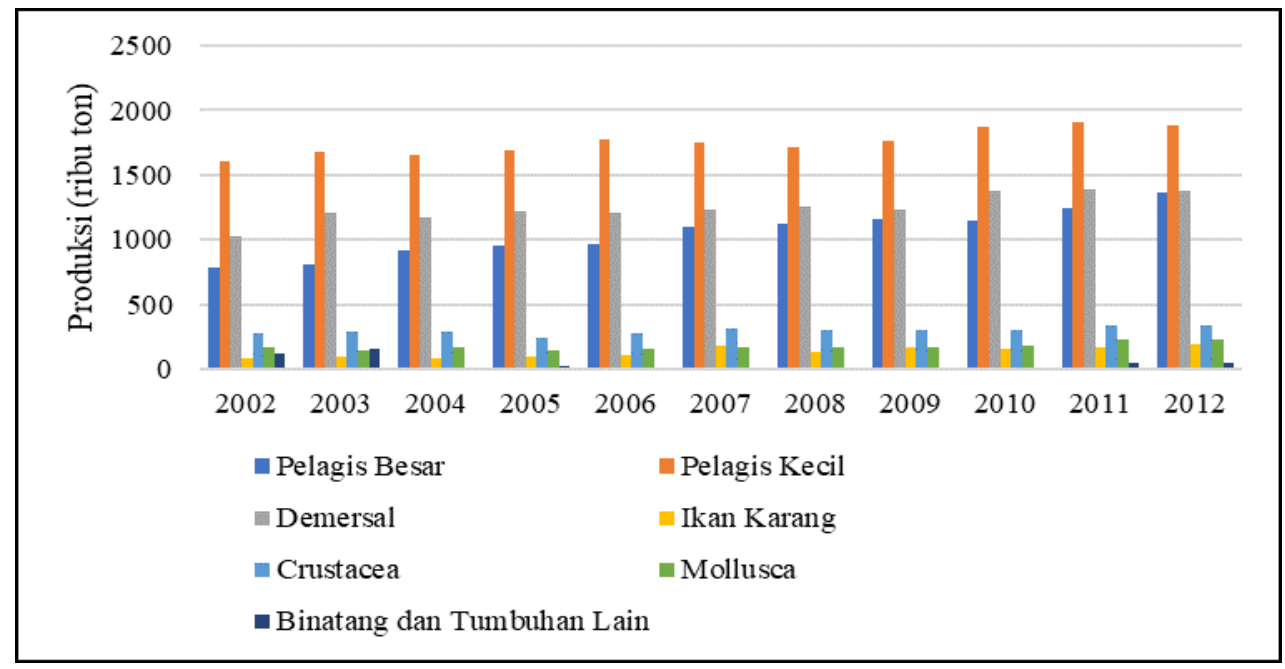

Sumber: Kementerian Kelautan dan Perikanan, diolah

Gambar 2. Produksi perikanan tangkap Indonesia menurut kelompok sumber daya perikanan tangkap di Indonesia tahun 2002-2012 (ribu ton)

Produksi perikanan tangkap Indonesia ditunjang oleh unsur-unsur unit penangkapan ikan, yakni nelayan sebagai pelaku penangkapan dan armada yang digunakan. Nelayan perikanan tangkap di laut Indonesia periode 2002 berjumlah 2.572 ribu jiwa, dan pada periode 2011 sebanyak 2.265 ribu jiwa. Jumlah nelayan perikanan tangkap di laut Indonesia mengalami penurunan dengan tingkat penurunan rata-rata sebesar $1,19 \%$ per tahun. Meskipun nelayan didominasi oleh nelayan kategori nelayan penuh dengan rata-rata proporsi sebesar $51,12 \%$ dari total nelayan, namun kategori nelayan ini merupakan kategori yang paling menyumbang laju penurunan nelayan tangkap di laut Indonesia dengan laju penurunan rata-rata per tahunnya sebesar 1,98\%. Sedangkan nelayan sambilan utama memiliki rata-rata proporsi sebesar $34,62 \%$, sedangkan nelayan sambilan tambahan $14,26 \%$ dari total nelayan tangkap di laut Indonesia.

Sedang pada unsur operasi armada, penangkapan ikan di perairan laut Indonesia merupakan penangkapan yang mengoperasikan berbagai macam alat tangkap (multigears). Rata-rata trip per tahun yang dilakukan pada periode $2002-2012$ sebesar $102.317,7$ ribu trip per tahun. Jumlah trip terendah yang dilakukan terjadi pada tahun 2002 (70.198,92 ribu trip), sedangkan jumlah trip tertinggi terjadi pada tahun 2009 (123.217,08 ribu trip). Sebagai penangkapan multigears, alat tangkap yang mendominasi frekuensi penggunaanya adalah pancing $(41,02 \%)$, dan jaring insang $(29,20 \%)$.

\section{Ekonomi Penangkapan Sumber Daya Perikanan Tangkap Laut Indonesia}

Ekonomi penangkapan terdiri dari biaya penangkapan, harga jual tangkapan, dan resource rent. Biaya penangkapan per unit sumber daya menggambarkan biaya yang dikeluarkan oleh nelayan untuk menangkap dan mendaratkan ikan. Pada periode 2002-2012, rata-rata biaya penangkapan per unit sumber daya sebesar Rp 5.628,69/kg. Biaya tersebut terdiri dari biaya antara yang meliputi biaya bahan bakar (bensin, solar, dan minyak tanah) dan biaya antara lain (olie, garam, es, umpan, bekal, pengankutan, ijin berlayar, retribusi, dan biaya berlabuh) sebesar Rp 4.120,05/kg (73,20\%), upah/gaji sebesar Rp 1.407,72 (25,01\%), serta biaya lainnya sebesar Rp 100,91 (1,79\%).

Biaya penangkapan per unit sumber daya perikanan tangkap laut memiliki variasi besaran pada masing-masing wilayah perairan pantai. Wilayah perairan pantai Utara Sulawesi merupakan wilayah dengan biaya penangkapan terkecil yakni sebesar Rp 5.197,00/kg. Sedangkan wilayah perairan pantai Maluku-Papua merupakan wilayah dengan biaya penangkapan tertinggi yakni sebesar Rp $5.939,64 / \mathrm{kg}$. Variasi biaya penangkapan terjadi karena perbedaan penggunaan alat penangkapan dan jenis kelompok sumber daya yang mendominasi penangkapan.

Variasi juga terjadi pada kondisi harga rata-rata per unit sumber daya perikanan tangkap laut di wilayah-wilayah perairan pantai. Pada tahun 2002-2012, harga rata-rata per unit sumber daya perikanan tangkap laut di Indonesia sebesar Rp 12.574,37/kg. Harga rata-rata per unit sumber daya 
perikanan tangkap laut tertinggi pada tahun 2002-2012 berlaku di perairan pantai Barat Sumatera (Rp $23.565,73 / \mathrm{kg}$ ). Sedangkan harga terendahnya berlaku di wilayah perairan pantai Selatan Jawa (Rp 7.727,73/kg).

Variasi yang terjadi pada harga rata-rata per unit dan biaya penangkapan per unit sumber daya perikanan tangkap laut, menjadikan rata-rata resource rent per unit sumber daya perikanan tangkap laut menjadi bervariasi pula. Rata-rata resource rent tertinggi tahun 2002-2012 berlaku di wilayah perairan pantai Barat Sumatera (Rp 17.851,91/kg), disusul oleh Timur Kalimantan (Rp $11.304,00 / \mathrm{kg}$ ), dan Timur Sumatera (Rp 9.983,00/kg). Sedangkan rata-rata resource rent terendah terjadi di wilayah perairan pantai Selatan Jawa (Rp 2.235,09/kg). Wilayah dengan rata-rata resource rent yang lebih tinggi menunjukkan kemanfaatan pengusahaan penangkapan perikanan tangkap laut yang lebih tinggi pula.

\section{Pemodelan Bioekonomi Sumber Daya Perikanan Tangkap Laut Indonesia}

Pemodelan bioekonomi Schnute dan Clark, Yoshimoto, Pooley (CYP) diestimasi dengan model regresi data penel. Terdapat tiga bentuk kemungkinan model regresi data panel yaitu common effect model (CEM), fixed effect model (FEM), dan random effect model(REM). Pemilihan model regresi panel terbaik pada setiap model bioekonomi dan wilayah perairan pantai dilakukan dengan uji formal, yakni minimal 2 uji dari kombinasi Uji Chow, Uji Hausman, dan Uji Lagrange-Multiplier. Selanjutnya, salah satu model bioekonomi dipilih berdasarkan kriteria ekonometrik dan representasi parameter biologis hasil pemodelan. Hasil pemilihan model bioekonomi dan penghitungan parameter biologis model bioekonomi terpilih digambarkan dalam Tabel 1.

Tabel 1. Hasil pemilihan model bioekonomi dan parameter biologis model bioekonomi terpilih

\begin{tabular}{|l|c|c|c|c|c|}
\hline \multicolumn{1}{|c|}{ Wilayah Perairan Pantai } & $\begin{array}{c}\text { Model } \\
\text { Bioekonomi }\end{array}$ & Model Regresi & $\mathrm{r}$ & $\mathrm{q}$ & $\begin{array}{c}\mathrm{K} \\
\text { (ton) }\end{array}$ \\
\hline Barat Sumatera & CYP & FEM & 2,3823 & $1,7 \mathrm{E}-05$ & $2,2 \mathrm{E}+08$ \\
\hline Selatan Jawa & CYP & FEM & 2,5187 & $2,4 \mathrm{E}-05$ & $6,3 \mathrm{E}+07$ \\
\hline Selat Malaka & Schnute & CEM GLS & 0,0159 & $6,4 \mathrm{E}-07$ & $1,0 \mathrm{E}+09$ \\
\hline Timur Sumatera & CYP & FEM & 2,7106 & $7,3 \mathrm{E}-06$ & $2,0 \mathrm{E}+08$ \\
\hline Utara Jawa & CYP & FEM & 1,9028 & $4,5 \mathrm{E}-06$ & $8,4 \mathrm{E}+08$ \\
\hline Bali-Nusa Tenggara & CYP & FEM & 1,2583 & $4,7 \mathrm{E}-06$ & $5,8 \mathrm{E}+08$ \\
\hline Selatan/Barat Kalimantan & CYP & CEM & 1,7668 & $1,5 \mathrm{E}-05$ & $3,2 \mathrm{E}+08$ \\
\hline Timur Kalimantan & CYP & CEM & 3,7764 & $2,5 \mathrm{E}-05$ & $1,2 \mathrm{E}+08$ \\
\hline Selatan Sulawesi & CYP & FEM & 5,5611 & $1,2 \mathrm{E}-05$ & $1,2 \mathrm{E}+08$ \\
\hline Utara Sulawesi & CYP & FEM & 5,3938 & $1,4 \mathrm{E}-05$ & $1,1 \mathrm{E}+08$ \\
\hline Maluku-Papua & CYP & FEM & 1,3720 & $2,2 \mathrm{E}-05$ & $1,2 \mathrm{E}+09$ \\
\hline
\end{tabular}

Parameter pertumbuhan intrinsik $(r)$, menunjukkan tingkat pertumbuhan alami biomassa perikanan tangkap laut. Wilayah perairan pantai Selatan Sulawesi merupakan wilayah yang memiliki kecepatan tingkat pertumbuhan alami terbesar. Artinya secara alami, biomassa di wilayah perairan pantai Selatan Sulawesi merupakan biomassa yang paling cepat tumbuh dibanding wilayah lainnya. Parameter koefisien kemampuan tangkap $(q)$, menunjukkan efisiensi teknis penangkapan ikan oleh alat tangkap dalam satu trip alat tangkap. Wilayah dengan efisiensi teknis tertinggi yaitu wilayah perairan pantai Timur Kalimantan. Sedangkan parameter daya dukung lingkungan $(K)$, memnujukkan kapasitas biomassa yang dapat ditampung oleh perairan di wilayah perairan pantai. Wilayah perairan pantai Maluku Papua yang memiliki daya dukung lingkungan tertinggi, memungkinkan untuk menampung biomassa yang lebih banyak dibandingkan wilayah lain.

\section{Neraca Aset Sumber Daya Perikanan Tangkap Laut Indonesia}

Stok dan dinamika perubahan sumber daya perikanan tangkap dihitung pada 11 wilayah perairan pantai di Indonesia. Selanjutnya agregasi dari nilai estimasi pada masing-masing wilayah perairan pantai akan menjadi penyusun stok dan dinamika perubahan pada neraca aset sumber 
daya perikanan tangkap laut Indonesia. Neraca aset fisik dan moneter sumber daya perikanan tangkap laut Indonesia periode 2002-2011 tersedia pada Lampiran 1 dan Lampiran 2.

Berdasarkan neraca aset fisik pada Lampiran 1, stok sumber daya perikanan tangkap laut Indonesia tahun 2002-2011 berkisar 172.005,80 - 216.515,16 ribu ton. Stok sumber daya tumbuh dengan laju rata-rata 2,47\% per tahun. Maximum Economic Yield (MEY) sebagai nilai pertumbuhan pada periode 2002-2011 berkisar antara 4.768,23 - 5.971,95 ribu ton. Pertumbuhan stok (MEY) merupakan potensi penangkapan yang berkelanmiliarn secara ekonomi penangkapan maupun biologis sumber daya. Pada periode 2002-2011 tingkat pemanfaatan sumber daya perikanan tangkap laut Indonesia berkisar 81,97-91,92\%. Kondisi demikian berarti bahwa secara umum, perairan Indonesia tidak mengalami economic overfishing. Meskipun demikian, apabila diteliti lebih dalam, pada periode 2002-2011 beberapa wilayah perairan pantai telah mengalami kondisi economic overfishing. Meskipun mengalami kecenderungan penurunan kuantitas wilayah yang mengalami overfishing, pada tahun 2011 wilayah perairan pantai Selat Malaka dan Selatan Sulawesi masih mengalami kondisi economic overfishing.

Tabel 2. Tingkat pemanfaatan sumber daya perikanan tangkap laut menurut wilayah perairan pantai Indonesia tahun 2002-2011 (persen)

\begin{tabular}{|l|r|r|r|r|r|r|r|r|r|r|}
\hline \multirow{2}{*}{ Wilayah Perairan Pantai } & \multicolumn{10}{|c|}{ Tahun } \\
\cline { 2 - 10 } & 2002 & 2003 & 2004 & 2005 & 2006 & 2007 & 2008 & 2009 & 2010 & 2011 \\
\hline Barat Sumatera & 80,82 & 84,78 & 83,99 & 52,85 & 60,81 & 78,44 & 86,00 & 93,51 & 90,92 & 93,92 \\
\hline Selatan Jawa & 147,41 & 161,87 & 103,99 & 86,98 & 80,71 & 94,77 & 77,09 & 128,04 & 71,81 & 88,76 \\
\hline Selat Malaka & 250,40 & 197,42 & 114,86 & 104,46 & 101,39 & 97,04 & 93,50 & 81,60 & 82,20 & 101,02 \\
\hline Timur Sumatera & 49,02 & 58,66 & 77,95 & 58,45 & 62,79 & 65,00 & 83,64 & 77,72 & 80,90 & 88,46 \\
\hline Utara Jawa & 102,90 & 100,22 & 96,17 & 99,14 & 100,35 & 101,89 & 94,33 & 91,13 & 92,20 & 96,69 \\
\hline Bali-Nusa Tenggara & 91,56 & 75,09 & 68,40 & 101,66 & 92,23 & 99,78 & 92,22 & 98,06 & 93,51 & 78,27 \\
\hline Selatan/Barat Kalimantan & 52,59 & 40,86 & 94,08 & 116,81 & 124,10 & 122,01 & 89,36 & 83,80 & 83,65 & 86,32 \\
\hline Timur Kalimantan & 88,14 & 91,14 & 68,08 & 71,14 & 63,39 & 65,47 & 67,22 & 60,48 & 76,40 & 67,47 \\
\hline Selatan Sulawesi & 75,88 & 85,87 & 79,90 & 107,27 & 102,48 & 118,57 & 103,76 & 104,81 & 99,68 & 113,38 \\
\hline Utara Sulawesi & 100,50 & 103,24 & 112,04 & 60,63 & 61,72 & 75,60 & 80,85 & 93,05 & 92,07 & 93,77 \\
\hline Maluku-Papua & 45,07 & 86,37 & 97,95 & 72,06 & 76,76 & 73,39 & 61,37 & 59,98 & 75,72 & 78,56 \\
\hline Indonesia & 81,97 & 91,92 & 89,91 & 80,26 & 81,88 & 86,43 & 82,57 & 82,58 & 85,22 & 89,51 \\
\hline
\end{tabular}

Deplesi merupakan indikator penting untuk menilai perekonomian penangkapan sumber daya perikanan tangkap laut. Nilai deplesi diperoleh dari selisih antara nilai forcasted growth (MEY) dengan nilai actual catch. Deplesi yang bernilai positif menandakan bahwa pemanfaatan sumber daya tidak optimum, karena terdapat sejumlah sumber daya yang berpotensi untuk ditangkap namun tidak tertangkap. Sedangkan, deplesi yang bernilai negatif menandakan nilai kerugian kelebihan pemanfaatan sumber daya perikanan tangkap laut (economic overfishing).

Tabel 3. Nilai deplesi sumber daya perikanan tangkap laut menurut wilayah perairan pantai Indonesia tahun 2002-2011 (miliar rupiah)

\begin{tabular}{|c|c|c|c|c|c|c|c|c|c|c|}
\hline \multirow{2}{*}{ Wilayah Perairan Pantai } & \multicolumn{10}{|c|}{ Tahun } \\
\hline & 2002 & 2003 & 2004 & 2005 & 2006 & 2007 & 2008 & 2009 & 2010 & 2011 \\
\hline Barat Sumatera & 554,66 & 500,57 & 557,95 & $2.638,45$ & $2.476,85$ & $1.700,51$ & $1.314,74$ & 753,85 & $1.148,44$ & 821,13 \\
\hline Selatan Jawa & 91,78 & $-140,51$ & 5,91 & 24,28 & 58,78 & 17,80 & 106,95 & 111,05 & 146,40 & 83,86 \\
\hline Selat Malaka & $1.237,62$ & $-1.136,26$ & 196,93 & 64,64 & 25,51 & 71,63 & 210,35 & 711,33 & 669,03 & 49,49 \\
\hline Timur Sumatera & $1.908,74$ & $1.506,47$ & 885,55 & $1.807,93$ & $1.802,18$ & $2.111,19$ & $1.289,81$ & $2.378,33$ & $1.967,11$ & $1.217,48$ \\
\hline Utara Jawa & 48,98 & 4,04 & 82,46 & 18,21 & 8,17 & 55,06 & 233,72 & 477,91 & 470,33 & 212,57 \\
\hline Bali-Nusa Tenggara & 61,65 & 256,25 & 362,83 & 15,91 & 85,90 & 3,19 & 147,96 & 46,55 & 171,30 & 882,72 \\
\hline Selatan/Barat Kalimantan & 329,48 & 526,73 & 58,84 & 153,00 & 230,74 & 269,66 & 186,68 & 381,46 & 415,98 & 366,01 \\
\hline Timur Kalimantan & 145,31 & 117,04 & 459,48 & 406,49 & 585,75 & 692,27 & 835,79 & $1.249,09$ & 815,62 & $1.225,29$ \\
\hline Selatan Sulawesi & 244,59 & 150,56 & 217,28 & 60,69 & 26,09 & 222,43 & 62,02 & 92,90 & 7,00 & 279,58 \\
\hline Utara Sulawesi & 2,37 & 15,24 & 64,86 & 423,72 & 448,54 & 316,68 & 341,49 & 136,41 & 169,59 & 147,86 \\
\hline Maluku-Papua & $1.712,34$ & 333,44 & 53,66 & $1.216,08$ & $1.135,83$ & $1.736,70$ & $3.226,42$ & $4.402,32$ & $2.909,60$ & $2.746,63$ \\
\hline Indonesia & $3.331,44$ & $1.944,45$ & $2.193,08$ & $6.301,62$ & $6.329,41$ & $6.325,26$ & $7.893,91$ & $10.426,20$ & $8.883,40$ & $7.654,05$ \\
\hline
\end{tabular}


Berdasarkan neraca aset moneter pada Lampiran 2, nilai deplesi Indonesia tercatat pada kisaran Rp 1.944,45-10.426,20 miliar. Sumber daya perikanan Indonesia secara umum belum dimanfaatkan sepenuhnya secara optimum. Namun, wilayah-wilayah perairan pantai yang mengalami economic overfishing sebagaimana terdapat pada Tabel 2, memiliki deplesi yang bernilai negatif. Berdasarkan Tabel 3, kerugian terbesar terjadi di wilayah perairan pantai Selat Malaka pada tahun 2002 dengan nilai kerugian Rp 1.237,62 miliar. Sedangkan penangkapan paling tidak optimum terjadi di wilayah perairan pantai Maluku Papua pada tahun 2009 dengan nilai Rp 4.402,32 miliar.

\section{KESIMPULAN}

Berdasarkan hasil yang telah dipaparkan, penelitian ini menarik kesimpulan bahwa neraca aset fisik dan moneter sumber daya perikanan tangkap laut Indonesia tahun 2002-2011 menggunakan pemodelan bioekonomi Schnute dan Clark Yoshimoto Pooley (CYP) berhasil disusun berdasarkan kerangka System of Environmetal-Economic Accounting for Fisheries (SEEAF). Dari neraca tersusun diketahui pada periode 2002-2011 tingkat pemanfaatan sumber daya perikanan tangkap laut Indonesia berkisar $81,97-91,92 \%$. Selain itu, nilai deplesi Indonesia tercatat pada kisaran Rp 1.944,45-10.426,20 miliar. Kondisi demikian berarti bahwa secara umum, perairan Indonesia tidak mengalami economic overfishing dan belum dimanfaatkan secara optimum. Meskipun demikian, apabila diteliti lebih dalam, pada periode 2002-2011 beberapa wilayah perairan pantai telah mengalami kondisi economic overfishing. Kerugian terbesar terjadi di wilayah perairan pantai Selat Malaka pada tahun 2002 dengan nilai kerugian Rp 1.237,62 miliar.

Berdasarkan penelitian yang telah dilakukan, saran yang dapat diberikan dari penelitian ini adalah volume Maximum Economic Yield (MEY) dalam neraca aset fisik sumber daya perikanan tangkap laut dapat digunakan sebagai volume Total Allowable Catch (TAC) dalam pengelolaan usaha penangkapan yang berkelanmiliarn secara ekonomi maupun biologis. Pengelolaan melalui Total Allowable Catch (TAC) yang berdasarkan volume Maximum Economic Yield (MEY) dapat dilakukan secara desentralisasi melalui pengelolaan trip armada yang melakukan produksi di setiap provinsi pada setiap wilayah perairan pantai. Selain itu, neraca aset sumber daya perikanan tangkap dapat dikembangkan oleh Badan Pusat Statistik (BPS) sehingga dapat menjadi dasar pertimbangan perumusan kebijakan pengelolaan perikanan oleh Kementerian Kelautan dan Perikanan (KKP).

\section{DAFTAR PUSTAKA}

Anderson, LG. (1986). The Economics of Fisheries Management. Baltimore:The Johns Hopkins University Press.

Anna, Zuzy. (2017). Indonesian Shrimp Resource Accounting Management for Sustainable Stock Management. Biodiversitas, 18(1), 248-256.

Atmaja, BS. Sadhotomo, B. Nugroho, D. (2011). Overfishing Pada Perikanan Pukat Cincin Semi Industri di Laut Jawa dan Implikasi Pengelolaannya. Jurnal Kebijakan Perikanan Indonesia, 3(1), 51-60.

Badan Pusat Statistik. (2018). Sistem Terintegrasi Neraca Lingkungan dan Ekonomi Indonesia 2013-2017. Jakarta: BPS.

Clark, C. (1985). Bioeconomic Modelling and Fisheries Management. Vancouver:John Wiley and Son, Inc.

Clarke, RP. Yoshimoto, SS. Pooley, SG. (1992). A bioeconomic analysis of the Northwestern Hawaiian Islands lobster fishery. Marine Resource Economic, 7(3),115-140.

Fauzi, A. \& Anna, Z. (2005). Pemodelan Sumber Daya Perikanan dan Kelautan untuk Analisis Kebijakan. Jakarta:PT Gramedia Pustaka Utama.

Fujita, R. (2008). Individual Fishing Quotas: A Win-Win Tool for Fisheries and Fishermen. New York:Environmental Defense Fund.

Hanneson, R. (1993). Bioeconomic Analysis of Fisheries. London:Fishing News Books.

Hilborn R. \& Walters CJ. (1992). Quantitative Fisheries Stock Assessment: Choice, Dynamics and Uncertainty. New York:Chapman and Hall.

Schaefer, MB. (1954). Some Aspect of Dynamics of Population Important to The Management of Commercial Marine Fisheries. Bull. Inter. Amer. Trop. Tuna Comm, 1, 25-56.

Schnute, J. (1987). A general fishery model for a size-structured fish population. Canadian J Fisher Aquatic Science, 44(5), 924-940. 
UN-FAO. (2004). Handbook of National Accounting: Integrated Environmental and Economic Accounting for Fisheries. Rome:FAO.

UNSD-FAO. (2012). System of Environmental-Economic Accounting Agriculture, Forestry and Fishery: SEEAAFF. Rome:FAO.

Zulbainarni, N. (2012). Teori dan Praktik Pemodelan Bioekonomi dalam Pengelolaan Perikanan Tangkap (Edisi Revisi). Bogor: IPB Press.

Zuzy, Anna. (2017). Indonesian Shrimp Resource Accounting Management for Sustainable Stock Management. Biodiversitas, 18(1), 248-256 


\section{LAMPIRAN}

Lampiran 1. Neraca aset fisik sumber daya perikanan tangkap laut Indonesia tahun 2002-2011 (ribu

\begin{tabular}{|c|c|c|c|c|c|c|c|c|c|c|}
\hline & \multicolumn{10}{|c|}{ Tahun } \\
\hline & 2002 & 2003 & 2004 & 2005 & 2006 & 2007 & 2008 & 2009 & 2010 & 2011 \\
\hline Opening & 172.00 & 185.77 & 184.02 & 194.31 & 196.86 & 203.18 & 206.14 & 213.41 & 216.5 & \\
\hline Stock & 5,8 & 1,69 & 7,44 & 6,86 & 6,34 & 1,24 & 5,44 & 7,83 & 15,16 & $213.581,86$ \\
\hline Pertumbuh & $4.969,3$ & $4.768,2$ & $4.808,5$ & $5.458,4$ & $5.503,1$ & $5.527,9$ & $5.694,3$ & $5.827,5$ & 5.913 & \\
\hline an (MEY) & 9 & 3 & 4 & 9 & 3 & 2 & 2 & 7 &, 45 & $5.9 / 1,95$ \\
\hline Penangkap & $4.073,5$ & $4.383,1$ & $4.323,3$ & $4.381,2$ & $4.505,7$ & $4.777,5$ & $4.701,9$ & $4.812,2$ & 5.039 & \\
\hline an & 1 & 0 & 1 & 2 & 9 & 2 & 5 & 4 &, 45 & $5.345,13$ \\
\hline Depletion & 895,88 & 385,13 & 485,23 & $\begin{array}{r}1.077,2 \\
7\end{array}$ & 997,34 & 750,40 & 992,37 & $\begin{array}{r}1.015,3 \\
4\end{array}$ & $\begin{array}{r}874,0 \\
1\end{array}$ & 626,22 \\
\hline $\begin{array}{l}\text { Other } \\
\text { Changes in } \\
\text { vol. }\end{array}$ & $\begin{array}{r}14.661 \\
77\end{array}$ & $\begin{array}{r}1.359,1 \\
3\end{array}$ & $\begin{array}{r}10.774 \\
65\end{array}$ & $\begin{array}{r}3.626,7 \\
5\end{array}$ & $\begin{array}{r}7.312,2 \\
4\end{array}$ & $\begin{array}{r}3.714,6 \\
0\end{array}$ & $\begin{array}{r}8.264,7 \\
6\end{array}$ & $\begin{array}{r}4.112,6 \\
7\end{array}$ & $\begin{array}{r}- \\
2.059 \\
29\end{array}$ & $-13.558,92$ \\
\hline Closing & 185.77 & 184.02 & 194.31 & 196.86 & 203.18 & 206.14 & 213.41 & 216.51 & 213.5 & \\
\hline Stock & 1,7 & 7,44 & 6,86 & 6,34 & 1,24 & 5,44 & 7,83 & 5,16 & 81,86 & $199.396,72$ \\
\hline
\end{tabular}
ton)

Lampiran 2. Neraca aset moneter sumber daya perikanan tangkap laut Indonesia tahun 2002-2011 (miliar rupiah)

\begin{tabular}{|c|c|c|c|c|c|c|c|c|c|c|}
\hline & \multicolumn{10}{|c|}{ Tahun } \\
\hline & 2002 & 2003 & 2004 & 2005 & 2006 & 2007 & 2008 & 2009 & 2010 & 2011 \\
\hline $\begin{array}{l}\text { Openi } \\
\text { ng } \\
\text { Stock }\end{array}$ & $\begin{array}{l}594.0 \\
05,49\end{array}$ & $\begin{array}{l}682.5 \\
88,11\end{array}$ & $\begin{array}{l}737.6 \\
29,05\end{array}$ & $\begin{array}{l}835.0 \\
09,58\end{array}$ & $\begin{array}{r}953.41 \\
7,86\end{array}$ & $\begin{array}{r}1.228 .8 \\
37,95\end{array}$ & $\begin{array}{r}1.577 .5 \\
80,83\end{array}$ & $\begin{array}{r}2.008 .2 \\
19,60\end{array}$ & $\begin{array}{r}2.145 .0 \\
96,55\end{array}$ & $\begin{array}{r}2.321 .3 \\
51,93\end{array}$ \\
\hline $\begin{array}{l}\text { Forec } \\
\text { asted } \\
\text { Growt } \\
\text { h }\end{array}$ & $\begin{array}{r}15.57 \\
8,51\end{array}$ & $\begin{array}{r}16.29 \\
6,63\end{array}$ & $\begin{array}{r}17.86 \\
8,02\end{array}$ & $\begin{array}{r}22.40 \\
4,32\end{array}$ & $\begin{array}{r}25.353 \\
33\end{array}$ & $\begin{array}{r}32.109 \\
57\end{array}$ & $\begin{array}{r}41.441, \\
05\end{array}$ & $\begin{array}{r}52.815 \\
72\end{array}$ & $\begin{array}{r}56.014, \\
35\end{array}$ & $\begin{array}{r}61.748 \\
86\end{array}$ \\
\hline $\begin{array}{l}\text { Actual } \\
\text { Catch }\end{array}$ & $\begin{array}{r}12.24 \\
7,08 \\
\end{array}$ & $\begin{array}{r}14.35 \\
2,18 \\
\end{array}$ & $\begin{array}{r}15.67 \\
4,94 \\
\end{array}$ & $\begin{array}{r}16.10 \\
2,71 \\
\end{array}$ & $\begin{array}{r}19.023 \\
92 \\
\end{array}$ & $\begin{array}{r}25.784 \\
31 \\
\end{array}$ & $\begin{array}{r}33.547 \\
14 \\
\end{array}$ & $\begin{array}{r}42.389 \\
52 \\
\end{array}$ & $\begin{array}{r}47.130 \\
94 \\
\end{array}$ & $\begin{array}{r}54.094, \\
81 \\
\end{array}$ \\
\hline $\begin{array}{l}\text { Deplet } \\
\text { ion }\end{array}$ & $\begin{array}{r}3.331 \\
44\end{array}$ & $\begin{array}{r}1.944 \\
45\end{array}$ & $\begin{array}{r}2.193 \\
08\end{array}$ & $\begin{array}{r}6.301 \\
62\end{array}$ & $\begin{array}{r}6.329,4 \\
1\end{array}$ & $\begin{array}{r}6.325,2 \\
6\end{array}$ & $\begin{array}{r}7.893,9 \\
1\end{array}$ & $\begin{array}{r}10.426 \\
20\end{array}$ & $\begin{array}{r}8.883,4 \\
0\end{array}$ & $\begin{array}{r}7.654,0 \\
5\end{array}$ \\
\hline $\begin{array}{l}\text { Other } \\
\text { Chang } \\
\text { es in } \\
\text { vol. }\end{array}$ & $\begin{array}{r}54.94 \\
1,38\end{array}$ & $\begin{array}{r}8.248 \\
44\end{array}$ & $\begin{array}{r}75.11 \\
5,24\end{array}$ & $\begin{array}{r}25.51 \\
5,75\end{array}$ & $\begin{array}{r}51.301 \\
07\end{array}$ & $\begin{array}{r}22.776 \\
30\end{array}$ & $\begin{array}{r}74.471 \\
31\end{array}$ & $\begin{array}{r}25.287 \\
50\end{array}$ & $\begin{array}{r}25.217 \\
00\end{array}$ & $\begin{array}{r}104.34 \\
6,49\end{array}$ \\
\hline $\begin{array}{l}\text { Closin } \\
\text { g } \\
\text { Stock } \\
\text { (prev. } \\
\text { years } \\
\text { Price) } \\
\end{array}$ & $\begin{array}{l}636.5 \\
09,55\end{array}$ & $\begin{array}{l}666.4 \\
00,87\end{array}$ & $\begin{array}{l}743.1 \\
18,12\end{array}$ & $\begin{array}{l}832.8 \\
82,31\end{array}$ & $\begin{array}{r}958.07 \\
2,92\end{array}$ & $\begin{array}{r}1.191 .2 \\
22,22\end{array}$ & $\begin{array}{r}1.565 .0 \\
95,18\end{array}$ & $\begin{array}{r}1.934 .4 \\
77,23\end{array}$ & $\begin{array}{r}2.094 .2 \\
50,36\end{array}$ & $\begin{array}{r}2.157 .2 \\
01,26\end{array}$ \\
\hline $\begin{array}{l}\text { Holdin } \\
\text { g } \\
\text { gain/l } \\
\text { oss }\end{array}$ & $\begin{array}{r}46.07 \\
8,57\end{array}$ & $\begin{array}{r}71.22 \\
8,18\end{array}$ & $\begin{array}{r}91.89 \\
1,46\end{array}$ & $\begin{array}{l}120.5 \\
35,55\end{array}$ & $\begin{array}{r}270.76 \\
5,03\end{array}$ & $\begin{array}{r}386.35 \\
8,61\end{array}$ & $\begin{array}{r}443.12 \\
4,42\end{array}$ & $\begin{array}{r}210.61 \\
9,32\end{array}$ & $\begin{array}{r}227.10 \\
1,57\end{array}$ & $\begin{array}{r}223.15 \\
4,26\end{array}$ \\
\hline $\begin{array}{l}\text { Closin } \\
\text { g } \\
\text { Stock }\end{array}$ & $\begin{array}{l}682.5 \\
88,11\end{array}$ & $\begin{array}{l}737.6 \\
29,05\end{array}$ & $\begin{array}{l}835.0 \\
09,58\end{array}$ & $\begin{array}{l}953.4 \\
17,86\end{array}$ & $\begin{array}{r}1.228 .8 \\
37,95\end{array}$ & $\begin{array}{r}1.577 .5 \\
80,83\end{array}$ & $\begin{array}{r}2.008 .2 \\
19,60\end{array}$ & $\begin{array}{r}2.145 .0 \\
96,55\end{array}$ & $\begin{array}{r}2.321 .3 \\
51,93\end{array}$ & $\begin{array}{r}2.380 .3 \\
55,53\end{array}$ \\
\hline
\end{tabular}

